\title{
THE EVOLUTION OF ISLAMIC STATE'S STRATEGY
}

\author{
Hussein Solomon \\ University of the Free State
}

\begin{abstract}
Despite having a vast number of forces arrayed against it - the United Statesled coalition, Putin's Moscow, Iran and its proxy, Hezbollah, Kurdish Peshmerga and the regimes in Baghdad and Damascus - Islamic State (IS) has expanded into other areas. Despite losing territory in Iraq and Syria, IS is growing in the Far East, the Caucasus and Africa. Reasons for the resilience displayed on the part of the jihadis are encouraging polarisation between groups and then benefiting from this process. Its diverse funding sources from oil sales to the trafficking of antiquities and narcotics have allowed IS to build a war chest in excess of US\$ 2 billion. With these funds, IS has deployed soft power - digging sewage systems and providing stipends to families - to earn the loyalty of its 'citizens'. IS has also displayed superior military strategy combining conventional military doctrine with asymmetric warfare. As IS are confronted with superior conventional forces in their heartland, however, they embrace more asymmetric warfare.
\end{abstract}

Keywords: Islamic State, Iraqi Special Forces, Kurdish Peshmerga, social media, funding, soft power

\section{Introduction}

One of the major reasons accounting for the failure of current counterterrorism efforts against IS jihadis is that they are underestimated. In fact, IS demonstrates sophisticated command of tactics and strategy - from military and psychological warfare to their exploits on social media. Moreover, IS has demonstrated an ability to adapt its tactics, and in a fast-evolving environment, exploiting its enemies' weaknesses and ensuring that it does not play to its enemies'

Scientia Militaria, South African

Journal of Military Studies, Vol 45, No. 1, 2017, pp. 21-44.

doi : $10.5787 / 45-1-1191$

Creative Commons License - CC BY NC-ND 4.0 strengths. In addition, accurately predicting its foes' responses, IS ensures that these responses work towards its broader strategy. IS is not merely a terrorist organisation and insurgency; it is also a proto-state and has 
access to political and economic instruments to bolster its nascent statehood. To understand its appeal and resilience, we need to explore its political instruments (increasing polarisation and sectarian strife, its deployment of soft power and its social media outreach), economic instruments, especially as it pertains to funding and administering its state, and its military strategy and tactics.

\section{Political instruments: Increasing polarisation and sectarian strife}

The overall political strategy of IS seems to want to increase polarisation and sectarian tensions as seen by the gruesome execution videos it routinely posts online of killings of Yazidis, Christians and the like whilst at the same time targeting those Muslims of a moderate disposition. Clearly, IS believes that it can only stand to benefit from the growing polarisation in society as in the words of the Brazilian revolutionary, Carlos Marighella, the "soft centre"2 would be eliminated. Following the barbaric attack on the Charlie Hebdo offices in Paris in January 2015, ${ }^{3}$ a wave of Islamophobia has swept Europe, which was intensified by another IS-inspired attack on Copenhagen in February 2015. ${ }^{4}$ In Dresden, Germany, for instance a group calling itself the Patriotic Europeans against the Islamification of the West (PEGIDA) soon spread to other cities in Germany, like Cologne, Hamburg, Munster and Stuttgart, bringing tens of thousands of people onto the streets in anti-Islam rallies. This has been replicated in other European capitals. ${ }^{5}$ Following the multiple terror attacks in France in November 2015, Islamophobia again increased across Europe. ${ }^{6}$ This Islamophobia is bound to antagonise an already alienated European Muslim community ${ }^{7}$ - hundreds of whom have already left to join IS. According to David von Drehle, ${ }^{8}$ the numbers of European Muslims who have fought in Syria and Iraq are:

$$
\begin{aligned}
& \text { France }=1200 \\
& \text { United Kingdom }=600 \\
& \text { Germany }=500-600 \\
& \text { Belgium }=440 \\
& \text { the Netherlands }=200-250 \\
& \text { Sweden }=150-180 \\
& \text { Denmark }=100-150 \\
& \text { Austria }=100-150 \\
& \text { Spain }=50-100 \\
& \text { Italy }=80 \\
& \text { Finland }=50-70 \\
& \text { Norway }=60 \\
& \text { Switzerland }=40 \\
& \text { Ireland }=30
\end{aligned}
$$


The return of these trained jihadis to their respective countries has also served to increase European citizens' security anxieties. Moreover, the tens of thousands of migrants fleeing IS from Syria, Iraq and other countries into Europe, have created the perfect opportunity for IS to infiltrate the masses of genuine refugees with their own trained operatives to wreak havoc in Europe. Given the waves of desperate humanity at their doors, many European countries did not have the opportunity to go through the necessary security checks for each and every migrant allowed into the European Union. In some instances, even rudimentary checks, like photographing and taking the fingerprints of these migrants, were not done. Under the circumstances, Aaron Brown ${ }^{9}$ estimates that IS has 4000 covert gunmen already in Europe, whom they have smuggled in amongst the refugees. The resultant fear amongst Europeans, made worse by the 2016 attacks on Brussels, has only served to fan the flames of Islamophobia further.

A similar hardening of attitudes is taking place across the Atlantic, in the United States, which has witnessed increased terrorist activity. On 3 May 2015, for instance, there was an IS-inspired assault on a Prophet Muhammed cartoon contest in Garland, Texas. The two individuals involved, Elton Simpson and Nadir Hamid Soofi, were in contact with IS. Simpson, it was subsequently discovered, was in Twitter contact with Muhammed Abdullahi Hassan aka Mujahid Miski, an IS recruiter from Minneapolis. ${ }^{10}$ By the end of 2014, 100 Americans had gone to Syria to join IS. ${ }^{11}$ Unsurprisingly, the US public is increasingly viewing Muslims as a threat. According to the Pew Research Centre, $42 \%$ of Americans say Islam is more likely than other religions to incite violence amongst its followers. ${ }^{12}$ From a strategic perspective, the attack on Garland gave fresh insights into the IS strategy and the challenge to policymakers. Whilst the militant group's Bayan Radio claimed responsibility for the attack and threatened Americans that "what is coming will be worse and more bitter", ${ }^{13}$ it is also clear that neither of the two assailants - Simpson and Soofi - received financial or military assistance from IS nor discussed their plans or even sought permission from IS. Rather, Daniel Pipes ${ }^{14}$ astutely observes that IS does not plan or direct its attacks on Western targets. Rather, it uses its high profile to incite Muslims against their non-Muslim neighbours. In other words, IS aims to inspire attacks, not plan or organise them. This perspective was reinforced when 24year-old Mohammad Youssuf Abdulazeez killed five servicemen in Chattanooga, Tennessee, and injured two others when he opened fire on an armed services recruiting centre and a military training facility. ${ }^{15}$

In 2014, IS also inspired such 'lone-wolf' attacks in Ottawa, Canada and Sydney, Australia. ${ }^{16}$ Whilst IS then ran a more centrally organised leadership in Iraq and Syria, its leadership was more decentralised outside of the territory it controlled. What inspires such lone-wolf attacks is its political ideology - a narrative of alleged 
grievances ${ }^{17}$ and a promise of a glorious future. This makes it extremely difficult for intelligence services to disrupt - the planning and organisation are done at individual level. This is highlighted in the case of Simpson. Despite the fact that he was under surveillance by authorities for over a year, the attack on Garland could not be thwarted before the event actually took place. This raises interesting questions about what is actionable intelligence, and legal questions about when a suspect could be apprehended.

What takes primacy in such terrorist attacks is not the magnitude of the terrorist attack itself, but rather the ability to terrorise a population. As insecurity, fear and anxiety grow, so too does Islamophobia. This Islamophobia, in turn, exacerbates Muslim disenchantment with Western societies and ultimately leads to more recruits into the Islamist cause.

\section{Political instruments: Islamic State's deployment of 'soft power'}

IS also understands that capturing territory is only one aspect of a total strategy; that in order to hold that territory, they also need to earn the trust of residents by providing basic services. IS jihadists have therefore fixed power lines, painted sidewalks, ran regular bus services, removed expired food from markets, dug sewage systems, and re-opened luxury hotels and offered three free nights with all meals included for newlyweds. In addition, they have started manufacturing prosthetic limbs for the wounded and provided rudimentary, if brutal, security to inhabitants of the nascent state they control. ${ }^{18}$

IS also established Islamic Services Committees to administer electricity supply, health spending, education, the cleaning of streets and the provision of food. ${ }^{19}$ Following the capture of Palmyra in Syria, IS also embarked on winning the loyalties of citizens by freeing prisoners at the notorious Tadmur Prison. This had huge symbolic significance since it was here where political dissidents of the Assad regime were not only imprisoned but also tortured. Since the start of the rebellion against Assad, the rebellion took on a distinct Sunni flavour. As a result, Tadmur Prison hosted many Sunni Islamists, including those of the Muslim Brotherhood. By freeing these prisoners, IS styled itself as the champion of Sunni interests against the ruling minority Alawite sect as represented by the Assad regime. ${ }^{20}$

IS is cognisant of the fact that both Iraq and Syria remain intensely tribal societies. Given the weakening of control of Baghdad and Damascus, tribal authorities have increasingly become more prominent in these conditions of state contraction. Recognising this, IS has established an emir in charge of tribal affairs Dhaigham Abu Abdullah - a Saudi national. ${ }^{21}$ This was an inspired choice - utilising 
a Saudi national to co-ordinate with and arbitrate between tribes as opposed to an Iraqi or Syrian national who would belong to one of the tribes and would therefore be open to accusations of bias. IS has co-opted tribal sheikhs through the use of various incentives. These included smuggling of contraband and dispensing greymarket rights. ${ }^{22}$ In return, IS expected the unswerving loyalty of these sheikhs.

In addition, recognising that fratricidal conflict was not in the best interests of their nascent state, IS has acted as mediator between tribes. For instance, in the Syrian town of Abu Kamal, there have been tensions between the al-Hassoun and the al-Rehabiyeen tribes for thirty years. In November 2014, IS deftly mediated in the dispute, affecting reconciliation between the elders of the two tribes to the relief of all in the town..$^{23}$ There have been times, however, when IS positions came under attack by tribal militias jealous of their autonomy being eroded by IS. Recognising that if they use their forces from pro-IS tribes to take on the hostile tribe, it would merely lead to more tit-for-tat fighting, which would undermine cohesion within the territory of IS, the jihadists pitted members of the same tribe against each other. In August 2014, for example, IS got members of the Shaitat tribe in Deir ez-Zor to turn on other members of their own tribe, which resulted in hundreds being killed. They accomplished this by means of supporting a younger generation of ambitious tribal leaders to turn against the older generation through the provision of funds and arms. ${ }^{24}$

IS also favours a fairly autonomous form of provincial governance. Under each province, local government is semi-autonomous as well. In practice, this means that "... local populations can effectively control their own economies through Shura [consultative] councils and are therefore more likely to respond positively and remain loyal to their new rulers" ${ }^{25}$ The ability to control one's own affairs at local level stands in sharp contrast to the over-centralising, ineffective and draconian rule emanating from the Iraqi and Syrian governments. Moreover, in deeply sectarian societies, such local governments can actually serve to minimise tensions between different groups. Even from a military standpoint, this provincial form of governance has advantages. It means that IS has active military units throughout the state it controls, that it has citizens willing to fight for it and/or support the military, and that IS can now fight on multiple fronts simultaneously. ${ }^{26}$

As a result, IS have won over much of the populace they control who compared them favourably with the neglect or oppression emanating from the Damascus and Baghdad governments. This would make the group harder to dislodge in future, despite recent temporary setbacks. IS also ensures the loyalty of its 31000 fighters (as of $2015^{27}$ ) by also involving the entire family unit. Whilst fighters receive US\$ 100 per month, another US\$ 100 goes towards the parents, and each of the 
fighters' siblings receives US\$ 40 per month. As Ben Hubbard ${ }^{28}$ has noted, it is a strategy designed to win over the entire family, and thereby the community.

\section{Political instruments: Islamic State and social media}

It is easy to understand the attraction to IS and the corresponding disenchantment of younger militants with Al-Qaeda with its ageing leadership and its inability to carry out a single major attack against the West. By contrast, IS through its slick recruitment videos - displays that it has carved out a large swathe of territory in Iraq and Syria, and its military successes in spite of Western airstrikes are appealing to a younger generation of would-be jihadis. Moreover, social media also allow IS to be in constant communication with its constituency and also allow IS to attract people outside of its cause as can be seen by the growing numbers of non-Muslims converting and joining the jihadis.

A key to the growth of IS, then, remains their ability to spread their ideology through the technologically savvy approach to social media propaganda - Facebook, Twitter, YouTube and Instagram. ${ }^{29}$ By March 2015, IS had 90000 Twitter accounts to spread their propaganda and recruit new jihadis. ${ }^{30}$ Just their English-language Twitter accounts have more than 21000 followers - the majority of these concentrated in the West. ${ }^{31}$ IS also makes extensive use of Zello. This is an encrypted application for mobile devices, which facilitates the sharing of audio messages. IS utilises this platform to distribute its religious sermons to a younger generation tired of traditional sermons given by established and establishment clerics. ${ }^{32}$ IS members extol the virtue of such social media in shaping the narrative on IS and therefore influencing the public perception of the organisation. "Don't hear about us, hear from us", was the popular refrain amongst these IS members when discussing their social media outreach. ${ }^{33}$ Nasser Balochi, a senior member of the IS social media team, could not emphasise the importance of social media enough when he declared, "This is a war of ideologies as much as it is a physical war. And just as the physical war must be fought on the battlefield, so too must the ideological war be fought in the media." 34

The use of rap music in their recruitment videos is especially appealing to young alienated youth and is a far cry from the staid videos in which the older generation of Al-Qaeda jihadis, like Osama bin Laden and Ayman al-Zawahiri, appeared. Instead of focusing on sermons from al-Baghdadi, as was the case with Al-Qaeda's leadership-centred videos, IS videos rather focus on the 'relatability' factor focusing on the IS rank and file. In addition, military successes with slick production techniques were the order of the day in these IS videos where a seductive narrative merged with powerful iconography. ${ }^{35}$ 
Cori Dauber and Mark Robinson of the University of North Carolina noted in a recent article the sophisticated visual techniques utilised by IS to enhance the quality of their propaganda videos. These range from "... choosing starkly contrasting colours - think black uniforms and orange jumpsuits - to the use of multiple cameras, tight focus, 'subjective' angles and intimate sounds to create an eyewitness effect". ${ }^{36}$ The care with which the terrorist group has approached its social media outreach suggests that it understands the value of social media in its communication and recruitment efforts. Beyond the quality of its postings, the sheer quantity is breath-taking. In a single week, IS produced 123 media releases in 6 languages, 24 of which were videos. ${ }^{37}$

Not all of these videos extol violence graphically depicting the decapitation of enemies of the caliphate. Whilst a fair number do demonstrate this, many others articulate well-worn Muslim grievances against the West as well as eulogising the virtues of the IS, i.e. building schools and operating clinics in the areas they control. In the process, they articulate a concrete and alternative vision to the purported corrupt, secular, Western-oriented state. In other words, they put forth a vision of a caliphate where full sharia law is practiced as a concrete reality. ${ }^{38}$ This has proved alluring. As Elizabeth Whitman ${ }^{39}$ has observed, recruits do not emanate only from those with militant backgrounds, but are increasingly attractive to middle-class Muslims who find the idea of a place where sharia law is applied in its purest form, appealing.

In addition to more generic videos, IS is quite adroit at creating videos for targeting specific constituencies and exploiting grievances of that community. ${ }^{40}$ In addition to recruitment via social media, ${ }^{41}$ IS also makes use of targeted recruitment via family networks. This was certainly the case of the Portsmouth 5. Five British Muslims from the town of Portsmouth, were recruited by means of an IS recruiter, 25-year-old Ifthekar Jaman, who was a cousin of Asad Uzzaman - one of the Portsmouth $5 .{ }^{42}$

As was outlined earlier, the aim of such aggressive social media presence is not only for IS to put forward its message but also to inspire lone-wolf terrorism as we witnessed in Garland and Tennessee. US Federal Bureau of Investigation (FBI) Director James B. Comey refers to this as "crowdsource terrorism" where thousands of messages are generated each month encouraging Americans to launch attacks inside the United States. ${ }^{43}$ Worryingly, the FBI has acknowledged that there are hundreds of investigations open in all 50 US states into individuals who have been receiving messages from IS and who may decide to act on such instigation. ${ }^{44}$ IS videos of extreme acts of violence, so graphically illustrated in its sadistic images of 
decapitations, also serve to terrify its enemies whilst instilling into its followers a sense of omnipotence. ${ }^{45}$

Thanks in part to persuasive social media, the penetration of IS ideology ${ }^{46}$ even in far-away South Africa is seen in the writings of an 18-year-old South African from Johannesburg using the pseudonym of Abu Hurayra al-Afriki who stated,

I joined the Islamic State because their aim is to establish the world of Allah [There is no God, but Allah] as the highest, and the word of Kufr [disbelief] as lowest, and this is what Allah tells us in the Qur'an to do. So it is a compulsory duty upon all the Muslims around the world to join the Jihad, although many of them are misguided and Allah did not choose them ... ${ }^{47}$

In the South African case, the power of IS social media is also reinforced by radical clerics on the ground working with disaffected youth. ${ }^{48}$

The power of IS social media was also evident in Nigeria where 24000 young people were stopped by authorities from leaving the country between January 2014 and March 2015. The majority of these were stopped from emigrating for fear that they were planning to join IS. ${ }^{49}$ Authorities account for the increase of IS recruits from Nigeria as a result of a combination of three factors: high youth unemployment, the alliance between Boko Haram and IS as well as the power of social media. Over and above the recruitment videos they put out, IS has also developed close ties with Nigerian criminal syndicates to arrange travel documents, visas, air tickets and money for their recruits. ${ }^{50}$ In addition, IS has assisted would-be recruits with sophisticated routes to hide their end destination from authorities. In August 2015, for instance, India arrested two Nigerian students who were attempting to cross into Pakistan and who eventually found their way to Iraq to join IS. ${ }^{51}$ In the Nigerian case, then, IS did not only actively recruit from Nigeria via social media, but also assisted would-be recruits to get to IS-controlled territory in the Middle East.

Exposure to IS social media played a key role in the radicalisation of 23year-old Tunisian engineering student Seifeddine Rezgui. Rezgui was a Real Madrid soccer fan and participated in break-dance competitions and rap music. ${ }^{52}$ Yet, within a few months of reading IS posts on social media, Rezgui, also known by the IS nom de guerre of Abu Yahya al Qayrawani, would kill 38 foreign tourists on a beach resort in Sousse with an AK-47. ${ }^{53}$ His last two postings on Facebook were indeed ominous. In the one he wrote, "If jihad is a crime, the world shall know that I'm a criminal." 54 In the other, the desperation and hopelessness in his tone is all too apparent, "May God take me out of this unjust world and perish its people and make them suffer. They just remember you when you die." 55 These words also remind us of the high youth unemployment in Tunisia. It was this same impoverishment and 
hopelessness which resulted in the self-immolation of a young street vendor in Sidi Bouzid in Tunisia, who ignited what came to be known as the Arab Spring. ${ }^{56}$ There seems to be a definite correlation between poverty and radicalisation. ${ }^{57}$ One survey conducted just after the 2015 Bardo attack in Tunisia's poorest region - the northwest - revealed that over half of the region's youth were willing to join IS. ${ }^{58}$ These structural conditions also served to make Rezgui more susceptible to radicalisation stemming from IS social media outlets.

Similarly, in June 2015, a 17-year-old Briton - Talha Asmal - enjoyed the dubious reputation of being that country's youngest suicide bomber when he detonated his SUV packed with explosives in Baiji - a northern Iraqi town. ${ }^{59}$ A week later, it emerged that three British sisters together with their nine children left the country to join their brother also in Syria with IS. In the case of both Asmal and the three sisters, what appealed to them was the ideological position of IS communicated via social media to establish an Islamic caliphate as this was “... laid out in sharia law, as a precursor to the Islamic Armageddon enshrined in Hadith literature, based on Prophet Mohammed's prophecy". 60

In addition to using social media platforms, IS is also adept at hacking their adversaries' Twitter accounts. On 12 January 2015, for instance, IS hacked into and took control of Twitter and YouTube accounts of the United States military's Central Command (CENTCOM). ${ }^{61}$ The IS member who undertook this operation was Junaid Hussain, a 21-year-old hacker from Birmingham, England who was a prominent member of the CyberCaliphate, an IS unit charged with conducting cyber warfare. ${ }^{62}$ Whilst the Pentagon was quick to announce that this breach of their cybersecurity did not compromise the security of sensitive documents, it was clearly an embarrassment to Washington and clearly a political coup for IS and their supporters, who likely would add further recruits to their ranks. The CyberCaliphate also deploys sophisticated encryption methods to avoid detection. ${ }^{63}$

Running a sophisticated social media programme, engaging in various social projects focusing on community upliftment, deploying softer power, all need financial resources. So how is IS funded?

\section{Economic instruments: Funding Islamic State}

With six out of ten oil fields in Syria and other such oil fields in Iraq under its control, IS is in possession of a vast war chest - estimated at US\$ 2 billion. $^{64}$ Moreover, IS makes an estimated US\$1 million per day through the sale and control of oil, according to the US Department of the Treasury. ${ }^{65}$ Much of this oil finds its way from the Syrian border town of Besaslan into Hatay, in Turkey - a half-hour 
drive. In Hatay, oil is a much-prized commodity on account of the high costs of 'black gold' in Turkey - US\$ 7,50 per gallon. ${ }^{66}$ Oil, however, has its drawbacks, given the falling price of crude oil on world markets. Oil installations are also vulnerable to airstrikes and as such, these IS-controlled oil facilities have been targeted repeatedly in air strikes. In recent months, IS has also been pushed back from these oil fields and they have been compelled to search for alternative revenue sources.

IS, as any corporation will do in turbulent times, is seeking to diversify its revenue stream. One such area is narco-trafficking. Currently, IS makes US\$ 1 billion per year from Afghan heroin trafficked through the territory it controls. There is also mounting evidence that IS has expanded its drug-trafficking operations in Libya. ${ }^{67}$ Libya, and specifically the area that it controls in the coastal region of Sirte, is also important for IS since this is the base of their human trafficking operations into the Mediterranean Sea. ${ }^{6}$ Perversely, many of those trafficked are refugees fleeing from Syria where IS played a major role in their displacement. Moreover, having created the conditions of death and destruction in Iraq, the authorities in Baghdad have also documented evidence where IS is playing a major role in organ trafficking. ${ }^{69}$

A further US\$ 1 million per day is accrued from extortion and taxation. ${ }^{70}$ For instance, pharmacy owners had to pay between US\$ 100 and US\$ 200 per month, whilst building contractors had to pay between 5 and 10 per cent from every building assignment to the group. ${ }^{71}$ The illicit sale of artefacts from Iraq and Syria also adds to their financial resources. ${ }^{72}$ This can be quite lucrative. In one incident, and from a single dig site, IS made US\$ 36 million. Some of these artefacts from this single dig site were over 8000 years old. ${ }^{73}$ The smuggling of raw materials is another source of income. ${ }^{74}$ In addition, IS has captured vast sums of money from bank vaults in towns it has captured. ${ }^{75}$ When IS took over Mosul, for instance, it looted the central bank and smaller provincial banks securing a financial windfall of hundreds of millions of dollars. ${ }^{76}$

Raqqa, the de facto IS capital, also happens to be the breadbasket of Syria. Cotton and wheat are produced here and sales of these products find their way once again into the coffers of IS. ${ }^{77}$ In Iraq, a similar dynamic is at play. IS-controlled territory in Iraq is where 40 per cent of the country's wheat is grown. ${ }^{78}$ In addition, kidnapping has proved to be an equally lucrative enterprise. During 2014, IS was paid US\$ 45 million in ransom payments. ${ }^{79}$ IS also receives funds from sympathisers around the world - most notably from such wealthy Gulf States like Qatar and Kuwait. ${ }^{80}$ David Cohen, the Under-Secretary for Terrorism and Financial Intelligence at the US Treasury, notes that both Qatar and Kuwait remain, 
"... permissive jurisdictions for terrorist financing". ${ }^{81}$ IS has also attracted donors from further afield. Terrorist financing to IS became clear at South Africa's OR Tambo International Airport when five South Africans were apprehended with US\$ 6 million in cash. ${ }^{82}$ The men were on their way from Johannesburg to Dubai, and the money seized was believed to have been destined for IS. ${ }^{83}$

All this provided IS with the requisite funds for its operational activities and to develop a patronage network earning them the support of locals. In the process, IS has displaced rival organisations in a given area. In Mosul and the wider Ninawa Province, the jihadist Jamaat Ansar al-Islam and the Ba'athist Jaysh Rijal al-Tariqat al-Naqshbandia were forced out by IS essentially buying over local communities. ${ }^{84}$

At the same time, the militant group keeps its operational costs low by providing small stipends as opposed to large salaries to its 'employees' and looting military equipment and appropriating infrastructure ${ }^{85}$ Ultimately, the deployment of its political and economic instrument is secondary to its military strategy and tactics. Without the successful deployment of force, IS would not be able to take over a given area. Without military victories, IS would not be able to galvanise its supporters through social media.

\section{Military instruments: Strategy and tactics}

Given the religious ideology of IS and its desire to create a caliphate based on the $7^{\text {th }}$-century model of governance of the first Islamic state, commentators often view the movement as anachronistic. However, there is nothing anachronistic about the military strategy and tactics of IS. Indeed, given the odds stacked against it, the group has displayed tremendous sophistication. One major reason for this sophistication in military prowess is the fact that the upper echelons of the organisation are dominated by hardened military professionals - many from Saddam Hussein's armed forces. Al-Baghdadi's chief of the general military council of IS was Abu Abdul-Rahman al-Bilawi (real name: Adnan Ismael Najm). He was a captain in Saddam Hussein's army and, like Al-Baghdadi, was also imprisoned at Camp Bucca. Al-Bilawi was killed in Mosul in June 2014. Another Saddam-era Iraqi officer was Abu Ali al-Anbari. Widely considered as Al-Baghdadi's deputy, he rose up the IS ranks on the basis of his military skills and political pragmatism and not because of his command of Islamic theology. Indeed, even amongst his IS supporters, Al-Anbari's knowledge of Islam is considered rudimentary. ${ }^{86}$ Another IS commander is Abu Omar al-Shishani (real name: Tarkhan Batirashvili) who served in the US-trained Georgian army as a military intelligence officer. He fought in the Russo-Georgian War of 2008. ${ }^{87}$ As with Al-Anbari, Al-Shishani's knowledge of Islam is limited. Indeed he is the butt of jokes on various jihadi forums where one 
noted that Al-Shishani's understanding of Islam is "shit". ${ }^{88}$ Unlike other jihadi organisations, one of the key reasons for IS success is the fact that senior appointments in the IS military hierarchy are based on military professionalism and not on religious faith. Conversely, Al-Shishani's death in Mosul in June 2016 will negatively affect the military prowess of the organisation.

Moreover, it is also important to recognise that the group has the dual capabilities to fight both conventional and asymmetric warfare on account of the weapons which are now in its arsenal. These are:

- 30 Soviet-era T-55 tanks;

- 10 newer T-72 battle tanks;

- $\quad$ SA-7 surface-to-air missile systems;

- BM-21 Grad multiple rocket launchers;

- Fim-92 Stinger Manpad shoulder-fired infrared homing surface-to-air missiles;

- ZU-23-2 anti-aircraft guns;

- M79 Osa, HJ-8 and AT-4 Spigot anti-tank weapons.

Its Cornet ATGM, meanwhile, has been used very effectively on the battlefield, for instance when it was deployed against Turkish armour. ${ }^{89}$ Often, IS would switch from conventional to asymmetric warfare and vice versa, in an attempt to confuse their opponents on the battlefield.

Following the IS loss of Kobane to Kurdish Peshmerga and US-led aerial bombardment and its loss of Tikrit to Iraqi Special Forces (ISF) in April 2015, ${ }^{90}$ many were already writing the group's obituary. Despite these setbacks, the group managed, a month later, in May 2015, to capture Ramadi, the capital of Iraq's Anbar Province as well as Palmyra in Syria. Commenting on this sudden reversal of fortunes, Tim Arango and Anne Barnard ${ }^{91}$ wrote:

Confounding declarations of the group's decline, the twin offensives have become a sudden showcase for the groups' disciplined adherence to its core philosophies: always fighting on multiple fronts, wielding atrocities to scare off resistance and, especially, enforcing its caliphate in the Sunni heartland that straddles the Iraqi-Syrian border. In doing so, the Islamic State has not only survived setbacks but has also engineered new victories.

Again, the choice of cities chosen for the offensive was strategic. Palmyra, despite its relatively small geographic size, has three main strategic advantages. First, the capture of the town gave IS access to new oil and gas fields. This is especially important given the US aerial attacks on the group's current oil infrastructure. Second, Palmyra sits astride a critical network of roads by which to move one's forces or to supply them. Third, it is an ancient site providing the 
militants with another lucrative source of revenues - the illicit trafficking of antiquities. ${ }^{92}$ Ramadi's strategic significance, meanwhile, lay in the fact that some Sunni tribes not only remained outside of IS but in some cases actively resisted the influence of IS over the Sunnis. ${ }^{93}$ With the capture of Ramadi, IS control over Iraq's Sunni heartland was now complete. It is also important to understand that there is a close interplay between IS military strategy and the articulation of its political goals. Shortly after the fall of Ramadi, IS started to speak on behalf of Sunnis in Iraq, articulating Sunni grievances against the Shia Baghdad government. In the process, this led to its enhanced perceived legitimacy ${ }^{94}$ amongst local Sunnis, thereby consolidating its military victory in the area.

From a tactical point of view, the IS strategy to capture Palmyra demonstrated excellent command of psychological warfare. Recognising that many of Assad's soldiers in the garrison were demoralised the group decided to add to this by decapitating dozens of soldiers and members of their families and widely disseminated the images. ${ }^{95}$ Hardly surprisingly, then, that the garrison at Palmyra did not put up a fight.

The tactical brilliance of IS commanders was on display in the capture of Ramadi. Here IS made use of the elements - in this case, timing their offensive with the appearance of a sandstorm, to ensure maximum confusion amongst the defenders of Ramadi. IS began their attack with 10 massive car bombs - each explosive having similar power to that of the Oklahoma truck bomb two decades before. ${ }^{96}$ These explosions levelled entire city blocks, creating mass confusion. At the same time, IS sleeper cells in Ramadi started attacking senior officers within the city, decapitating command and control within the armed forces. At this point, the ground offensive started. The remaining Iraqi troops then fled the city. Despite being outnumbered by Iraqi forces, the superior tactics of IS won them the city.

In the run-up to the attack on Ramadi, IS also revealed its deep knowledge of the Iraqi armed forces - demonstrating their ability to reconnoitre and gather intelligence on their targets. Recognising that regular Iraqi forces scarcely provide a challenge to it and recognising that Iraqi Special Forces (ISF), who were trained and armed by the United States, constituted its real threat, it sought to ensure that the ISF were as dispersed as possible. In the weeks before their major Ramadi offensive, IS deliberately embarked on several minor operations whose aim was to stretch the ISF to the maximum. As a result, at the time of the offensive on Ramadi, the ISF were dispersed $^{97}$ across several theatres and could not respond to the capture of Ramadi. By July 2015, IS forward positions were a mere 65 kilometres from Baghdad. ${ }^{98}$

Recognising how dire the situation actually was for his beleaguered government, Iraqi Prime Minister Haider al-Abadi attempted to recapture Ramadi, 
the key to the retake of Anbar Province, in August 2015. However, two Iraqi generals - Major General Abdulrahman Abu Ragheef and Brigadier General Safeen Abdulmajid - central to the planned offensive were killed by IS. IS made use of captured American Humvees, which allowed the suicide bombers driving the explosive-laden vehicles to appear as Iraqi soldiers, allowing them to get close to the generals before detonating their lethal cargoes. ${ }^{99}$ In addition to respectively killing the deputy head of Anbar Operations Command and the head of the Iraqi Army's $10^{\text {th }}$ Division, a number of roadside bombs as well as booby-trapped buildings had resulted in large-scale casualties amongst Iraqi soldiers preparing for the planned offensive. Needless to say, this not only sapped morale, but it also resulted in no major offensive on Ramadi ${ }^{100}$ in August 2015. Ramadi was only recaptured with the assistance of US Special Forces several months later.

Given the strategic importance of Libya to Europe and Africa, it is important to reflect on this troubled country and the advances of IS. In this case, 20 October 2011 marked the capture and killing of Libyan strongman, Colonel Muammar Gaddafi. ${ }^{101}$ What followed was a short-lived period of hope as Libyans contemplated democratic reforms following almost 42 years of authoritarian rule. Hopes were dashed as the political vacuum was increasingly filled by IS and Islamist-affiliated IS groups. In July and October 2014, Benghazi and Derna respectively fell under IS control. ${ }^{102}$ Since then, IS has expanded the territory under their control in Libya, making major advances to the east, south and west of Sirte, including the capture of the Gadabya air base. ${ }^{103}$ IS fighters were also making headway towards Misrata on the coastal road to Tripoli. Here again, IS fighters in Libya were being quite innovative in tactics using a combination of asymmetric tactics and conventional warfare. Conventional IS forces only advance after individual suicide bombers as well as those in cars have detonated their explosives thereby sowing maximum confusion. As IS fighters advanced on Misrata, suicide bombers wreaked havoc on the city by detonating their bombs. In one such incident on 31 May 2015, five people were killed and a further eight wounded ${ }^{104}$ - a clear example of psychological warfare. We have seen these tactics being used more recently in IS advances in Palmyra in Syria and Ramadi in Iraq. ${ }^{105}$ The sophistication of IS military strategy in Libya was also seen in the fact that their targets were specifically chosen, such as the great man-made river water project - the largest irrigation scheme in the world which supplied fresh water to Libya's parched cities. ${ }^{106}$ Power stations were also targeted. The increased sophistication of attacks seemed to be related to the influence of Gaddafi's former officers, who alienated from the status quo in which they were marginalised. ${ }^{107}$

The IS modus operandi is quite clear across North Africa: exploit existing grievances in a particular area, utilise returning IS fighters to serve as a force 
multiplier for existing local militias who have pledged allegiance to the group and, in order to ensure command and control from IS central, send one of the senior IS commanders as the leader of the local franchise. It is this strategy, which was used with such devastating results when young militants of the Islamic Youth Shura Council managed to capture Derna in north-eastern Libya. ${ }^{108}$ This strategy was also evident in July 2014, when rival groups fought for control of Benghazi in Libya. Ansar al-Sharia's alignment with IS proved decisive. Libyans who fought in Iraq and Syria were ordered to return to their home country and fight on the side of Ansar alSharia. These hundreds of battle-hardened veterans proved decisive in Ansar alSharia's capture of several parts of Benghazi. ${ }^{109}$

It is important to understand that IS expansion and penetration into regions and countries are not willy-nilly but strategic. Nigeria, for instance, is Africa's most populous country, it has the biggest economy and is a regional hegemon in West Africa. The strategic importance of Nigeria for IS should not be underestimated. As Peter Pham ${ }^{110}$ recently noted about Boko Haram -

We have a group holding territory and shooting down jet fighters ... If Nigeria collapses - it is the strong state in the region - there are no strong states to contain what would happen if Boko Haram succeeds in carving out an Islamic state in that area.

In similar fashion, Tunisia, too was targeted by IS because, according to Larry Diamond, ${ }^{111}$ it is "Alone among the Arab States, it has achieved a remarkable level of political compromise among secular parties and the principal Islamist party, Ennhada". Indeed, the moderate Islamists of Ennahda has one minister and three junior ministers in the coalition government. ${ }^{112}$ The terrorist attack on 18 March 2015 on the Bardo Museum in Tunis in which 21 foreign tourists were killed and a further 42 were injured $^{113}$ as well as the 26 June 2015 deadly assault on Sousse, a beach resort, which resulted in 38 foreign tourists killed ${ }^{114}$ then aimed to undermine Tunisia's relative success at forging a democracy with compromises between secularists and moderate Islamists. From this perspective, the objective of the attacks was to cause greater polarisation within society between those who are liberalminded and those who are religiously-oriented. With more than 3000 Tunisian trained jihadis having returned to their home country after receiving training in camps in Iraq, Libya and Syria, ${ }^{115}$ one could expect more attacks in the future.

IS strategy in the West, of course, is different as it cannot control territory in non-Muslim-dominated regions. As such, its strategy of terrorism is aimed, as explained earlier, to increase polarisation and get the authorities to overreact. The attacks on Paris in January 2015 - on a Jewish market and the offices of the Charlie Hebdo magazine - meanwhile illustrate part of the group's modus operandi in 
Europe. The three perpetrators - brothers Chérif and Said Kouachi ${ }^{116}$ and Amedy Coulibaly ${ }^{117}$ - were well known to the security forces and had indeed spent time at the notorious Fleury-Mérogis prison in Paris together ${ }^{118}$ and were under surveillance by French authorities. Knowing this, they simply outlasted the resources and attention span of French intelligence agencies by doing nothing untoward to attract attention. Once sure that surveillance had ended, they struck. ${ }^{119}$ This, in turn, raises questions for intelligence services everywhere of how does one with limited resources maintain surveillance for months on hundreds of targets simultaneously? This is made worse by the budgetary constraints as a result of austerity measures undertaken by various Western governments. Under the circumstances, Western security experts have become quite pessimistic regarding their ability to end global jihad. Robert Grenier, a former Central Intelligence Agency (CIA) counter-terrorism expert glumly stated, "The forces of global jihad which Osama bin Laden did so much to inspire are stronger than ever." ${ }^{120}$ Equally pessimistic, Andrew Parker, the head of Britain's domestic intelligence service noted than an attack on the United Kingdom was highly likely. ${ }^{121}$

The Paris attacks were also interesting from another perspective. It was the first time that Al-Qaeda - more specifically the Yemeni-based Al-Qaeda in the Arabian Peninsula (AQAP) - and IS worked together in a joint operation. The Kouachi brothers were recruited by AQAP following orders from Al-Qaeda's emir - Ayman al-Zawahiri - to strike at the Charlie Hebdo offices. ${ }^{122}$ The attack on the Jewish market meanwhile was undertaken by an IS recruit - Amedy Coulibaly. Phone records subsequently revealed that the Kouachi brothers and Coulibaly exchanged scores of phone calls in the run-up to and during the attacks. Could this be the start of further cooperation between IS, Al-Qaeda and other radical Islamists? Interesting as such a line of questioning may seem, it appears that this was a onceoff, given the deep rivalry between IS and Al-Qaeda. Rather, the co-operation in Paris seems a direct result of personal ties forged in the French prison amongst the perpetrators of this attack.

The Paris attacks were important for a different reason too. It demonstrated that these radical Islamists could learn from past mistakes and adapt their tactics to new circumstances, in particular out-waiting their respective surveillance details. The November 2015 Paris attacks also displayed increasing sophistication in IS attacks. Here, multiple targets were engaged utilising a combination of suicide bombers and gunmen spraying bullets. In the attacks, 150 people were killed and hundreds more wounded. The targets chosen included a restaurant, a soccer stadium and a nightclub. ${ }^{123}$ Whilst seemingly randomly chosen, the very ordinariness of the targets selected was designed to spread terror - an ordinary Parisian going about his 
or her ordinary business can be targeted anywhere. The ordinariness of the targets was designed to instil terror amongst Parisians.

\section{Conclusion}

With their recent loss of Mosul to Iraqi forces, IS is certainly losing territory with some analysts arguing that their de facto capital Raqqa, in Syria, will soon be next. Indeed, by January 2017, they had lost more than 50 per cent of the territory they had controlled at the end of December 2015. ${ }^{124}$ At the same time, it is too early to write the group's obituary. As this article has emphasised, IS remains extremely adaptable, and has increasingly moved away from fighting conventional battles with the superior forces deployed against them and having engaged in more terrorist attacks. On 22 March 2017, an IS-inspired terrorist, Khalid Masood, drove his vehicle into crowds at the Westminster Houses of Parliament in London. In this terrorist atrocity, 18 people were killed and 50 injured. ${ }^{125}$ In similar vein, another IS attack took place in the St Petersburg metro in Russia in April 2017. An explosive device detonated and resulted in the deaths of 11 people with a further 51 being injured. ${ }^{126}$ Unfortunately these attacks are extremely difficult to prevent for the security services given the fact that planning is often done at individual level. With the loss of its heartland, IS-inspired terrorist attacks, such as those in London and St Petersburg, will increasingly be the central feature of the IS modus operandi.

What is lacking on the part of the international community is a holistic response to the multi-faceted threat posed by IS. Whilst the world celebrates the jihadi losses in Palmyra, Ramadi and Mosul, the group strikes at Jakarta and Brussels. Whilst the international community congratulates itself for destroying IS oil refineries, the group involves itself in more lucrative narco-trafficking, human trafficking and organ trafficking funding avenues. Whilst intelligence services report on the death of IS fighters as a result of drone strikes, the group continues to recruit via its social media outreach. Comprehensive approaches are needed that would view the struggle against IS over the long term, as opposed to euphoria surrounding shortterm, often pyrrhic, victories.

\section{Endnotes}

${ }^{1}$ Professor Hussein Solomon lectures in the Department of Political Studies and Governance at the University of the Free State. The author acknowledges the financial support of the National Research Foundation (NRF), which made this publication possible. The author, however, is solely responsible for the contents of this article. 
2 JW Williams. "Carlos Marighella: The father of urban guerrilla warfare". Studies in Conflict and Terrorism 12/1. 1989. 1-20.

${ }^{3}$ D von Drehle. "The European Front". Time. 26 January 2015. 18.

${ }^{4}$ A Tausch. "Estimates on the global threat of Islamic State terrorism in the face of the 2015 Paris and Copenhagen attacks". Rubin Center. 13 July 2015. <http://www.rubin.center.org/2015/07/estimates-on-the-global-threat-of-islamicstate-terrorism> Accessed on 29 July 2015.

${ }^{5}$ L Deardon. "Germany anti-Islam protests: Biggest Pegida march ever in Dresden as rest of Germany shows disgust with lights-out". The Independent. 5 January 2015. <http://www.independent.co-uk/news/world/europe/germanyantiislam-protests-biggest-pegida-march-ever-in-dresden-as-rest-of-germany-showsdisgust> Accessed on 21 April 2015.

${ }^{6}$ D Pipes. "Why the Paris massacre will have limited impact". National Review Online. 14 November 2015. <http://www.meforum.org/5628/parismassacre-impact $>$ Accessed on 15 November 2015.

${ }^{7}$ Tausch op. cit., p. 4.

${ }^{8}$ Von Drehle op. cit., 18-19.

${ }^{9}$ A Brown. "'Just wait ...' Islamic state reveals it has smuggled thousands of extremists into Europe”. Daily Express. 10 September 2015. <http://www.express.co.uk/news/world/55434/Islamic-State-ISIS-SmugglerThousands-Extremists-into-Europe-Refugees> Accessed on 14 September 2015.

${ }^{10}$ D Pipes. "IS attacks on the West". The Washington Times. 22 May 2015. <http://www.meforum.org/5255/IS-attacks-the-west> Accessed on 4 June 2015.

${ }^{11}$ A Masi. "ISIS, aka Islamic State, warns of sleeper cells attacks on US interests in retaliation for bombings". IB Times. 8 August 2015.

<http://www.ibtimes.com/isis-aka-islamic-state-warns-sleeper-cell-attacks-usinterests-retaliation-bombings-1653476> Accessed on 1 December 2015.

${ }^{12}$ K Abdul-Jabbar. "Paris was not about religion". Time. 26 January 2015.

13 Pipes, "IS attacks on the West" op. cit.

14 Ibid.

${ }^{15}$ B Bennett. "FBI directors says Islamic State poses greater threat to U.S. than Al Qaeda". LA Times. 22 July 2015. <http://www.latimes.com/nation/la-na-fbicomey20150722-story.html>Accessed on 28 July 2015.

${ }^{16}$ MR Gordon \& E Schmitt. "Iran still aids terrorism and bolster's Syria's president, State Department finds". The New York Times. 19 June 2015. <http://nytimes.com/2015/06/20/world/middleeast/state-department-terrorismreport-iran>Accessed on 1 July 2015.

${ }^{17}$ Ibid.

${ }^{18}$ B Hubbard. "Offering services, IS digs in deeper in seized territories". The New York Times. 16 June 2015. <http://www.nytimes.com/2015/06/17/world/middleeast/offering-services-ISensconces-itself> Accessed on 17 June 2015.

${ }^{19}$ AJ Al-Tamimi. "The evolution in Islamic State administration: The documentary evidence”. Rubin Centre. 6 August 2015.

<http://www.rubincenter.org/2015/08/the-evolution-in-islamic-state-administrationthe> Accessed on 17 August 2015. 
${ }^{20}$ A Barnard \& T Arango. "Using violence and persuasion, IS makes political gains". The New York Times. 3 June 2015.

<http://www.nytimes.cim/2015/06/04world/IS-making-political-gains-.html>

Accessed on 4 June 2015.

${ }^{21} \mathrm{M}$ Weiss \& H Hassan. ISIS: Inside the army of terror. New York, NY:

Regan Arts, 2015, 207.

22 Ibid., p. 200.

23 Ibid., p. 207.

${ }^{24}$ Ibid., pp. 205-206.

25 AB Atwan. "When it comes to 'Islamic State', the West just doesn't get

it”. Open Democracy. 9 July 2015. <https://www/opendemocracy.net/arab-

awakening/abdel-bari-atwan/when-it-comes-to>Accessed on 14 September 2015.

${ }^{26}$ Ibid.

${ }^{27}$ ADF. "Feature: IS moves into Africa". Defence Web. 29 July 2015.

$<$ http://www.defenceweb.co.za/index.php?option=com_content $\&$ view=article $\&$ id $=4$

01> Accessed on 3 August 2015.

${ }^{28}$ Hubbard op. cit.

${ }^{29}$ ADF op. cit.

${ }^{30} \mathrm{~J}$ Hall. "'IS controls as many as 90,000 Twitter accounts which it uses to spread sick propaganda and radicalise Westerners, terror experts reveal". Mail Online. 6 March 2015. <www.dailymail.co.uk/news/article-2982673/IS-controls90000-twitter-accounts-which-it-uses-to-spread-sick-propaganda-and-radicalisewesterners-terror-experts-reveal.html> Accessed on 10 July 2015.

${ }^{31}$ Bennett op. cit.

${ }^{32}$ Weiss \& Hassan op. cit., p. 173.

${ }^{33}$ Ibid., p. 170.

${ }^{34}$ Quoted in J Stern \& JM Berger. ISIS: The state of terror. London:

William Collins, 2015, 147.

35 ADF op. cit.

36 "The Islamic State: The propaganda war". The Economist. 15 August

2015. <http://www.economist.come/news/middle-east-and-africa/21660989terrorists-vicious $>$ Accessed on 17

August 2015.

${ }^{37}$ Ibid.

${ }^{38}$ Ibid.

${ }^{39}$ E Whitman. "Islamic State recruitment: IS seeks fighters from Caucasus, Central Asia and Indonesia”. IB Times. 13 August 2015.

<www.ibtimes.com/islamic-state-recruitment-IS-seeks-fighters-caucasus-central> Accessed on 17 August 2015.

${ }^{40}$ Gordon \& Schmitt op. cit.

${ }^{41}$ Whitman op. cit.

${ }^{42}$ E Saner. "Mundane reality of martyrs". Mail and Guardian. 31 July - 6 August 2015. 16.

${ }^{43} \mathrm{ADF}$ op. cit.

${ }^{44}$ Ibid.

${ }^{45}$ Atwan op. cit. 
${ }^{46} \mathrm{P}$ Tilsley. "South Africa increasingly seen as key ISIS pipeline for jihadis, cash". Fox News. 3 October 2015.

<http://www.foxnews.com/world/2015/10/03/south-africa-increasingly-isis-pipelinefor-jihadis-cash> Accessed on 10 October 2015.

${ }^{47}$ Quoted in H Solomon. "South Africa and the Islamic State". RIMA

Occasional Papers 3/3. April 2015.

<http://muslimsinafrica.wordpress.com/2015/04/09/south-africa-and-the-islamicstate-professor-hussein-solomon> Accessed on 21 April 2015.

48 Tilsley op. cit.

49 'Nigeria 'blocks recruitment' by Islamic State”. Starr FM Online. 11

August 2015. <http://starrfmonline.com/1.5908766> Accessed on 12 August 2015.

${ }^{50}$ Ibid.

${ }^{51}$ Ibid.

${ }^{52}$ C Freeman \& H Morajea. "Tunisia-Gunman: The gunman who loved

Facebook and Real Madrid”. The Sunday Telegraph. 28 June 2015. 2.

53 "The Islamic State group on Saturday claimed responsibility for a

massacre in a Tunisian seaside resort that killed nearly 40 people, most of them

British tourists, in the worst attack in the country's recent history". France24.com.

<http://www.france24.com/en/20150627-is-group-tunisia-massacre-sousse>

Accessed on 1 July 2015.

${ }^{54}$ Freeman \& Morajea op. cit.

55 Ibid.

${ }^{56}$ A Bruno. "Tunisia's terrorism problem goes beyond Islamic State".

Geopolitical Monitor. 14 July 2015. < http://geopoliticalmonitor.com/tunisias-

terrorism-problem-beyond-islamic-state> Accessed on 15 July 2015.

${ }^{57}$ D Cohen \& D Levin. "How IS gained traction in the Middle East".

Forbes. 10 August 2015. <http://www.forbes.com/sites/realspin/2015/08/10/how-ISgained-traction-in-the-middle-east $>$ Accessed on 12 August 2015.

${ }^{58} \mathrm{Al}$ Jazeera Centre for Studies. "Tunisia's security crisis and government's inability to cope". AMEC Insights. Briefing no. 13/2015. 27 July 2015. 2.

59 T Fatah. "Face reality: Many Muslims support IS". The Toronto Sun. 16 June 2015. <http://www.meforum.org/5331/many-muslims-support-IS > Accessed on 17 June 2015.

${ }^{60}$ Ibid.

${ }^{61}$ Von Drehle op. cit., p. 18.

${ }^{62} \mathrm{~K}$ de Freyas-Tamura. "Junaid Hussain, IS recruiter, reported killed in airstrike”. The New York Times. 27 August 2015.

<http://www.nyimes.com/2015/08/28/world/middleeast/junaid-hussain-islamicstate-recruiter $>$ Accessed on 31 August 2015.

${ }^{63}$ Atwan op. cit.

${ }^{64}$ Abukar, H.M. "Is IS aligned to or influencing African jihadi groups?

African Arguments. 28 October 2014. http://africanarguments.org/2014/10/28/is-ISallied-to-or-influencing-african-jihadi-groups-by-hassan-m-abukar. Accessed: 10

March 2015

${ }^{65}$ Abdul-Jabbar op. cit., p. 15. 
${ }^{66} \mathrm{~S}$ Bronstein \& D Griffin. "Self-funded and deep-rooted: How ISIS makes its millions". CNN. 7 October 2014.

<http://edition.cnn.com/2014/10/06/world/meast/isis-funding>Accessed on 26

November 2014.

67 "Islamic State group now controls key drug trafficking routes". teleSUR.

30 July 2015. <http://www.telesur.tv.net/english/news/Islamic-State-Group-Now-

Controls-Key-Drug-Trafficking > Accessed on 19 September 2015.

${ }^{68}$ Ibid.

${ }^{69}$ Ibid.

${ }^{70}$ S Almukhtar. "IS finances are strong”. New York Times. 19 May 2015.

<http://www.nytimes.com/interactive/2015/05/19/world/middleeast/IS-

finances.html>Accessed on 2 June 2015.

${ }^{71}$ Al-Tamimi op. cit.

72 B Hubbard. "IS appears to destroy 2 Palmyra tombs, flaunting wreckage in photos". The New York Times. 24 June 2015.

<http://www.nytimes.com/2015/05/25/world/middleeast/islamic-state-IS-destroyspalmyra $>$ Accessed on 1 July 2015.

${ }^{73}$ ADF op. cit.

${ }^{74}$ Ibid.

75 Von Drehle op. cit., p. 18.

${ }^{76}$ Bronstein \& Griffin op. cit.

77 Ibid.

${ }^{78} \mathrm{H}$ Alexander \& A Beach. "How ISIL is funded, trained and operating in Iraq and Syria". The Telegraph. 23 August 2014.

<http://www.telegraph.co.uk/news/worldnews/middleeast/iraq/11052919/How-Isilis-funded-trained-and-operating-in-Iraq-and-Syria.html $>$ Accessed on 20 November 2014.

79 "ISIS got up to $\$ 45$ million in ransoms in past year, UN says". Time Magazine. 10 November 2014I. <http://time.com/3605061/isis-ransom-unitednations $>$ Accessed on 26 November 2014.

${ }^{80}$ Bronstein \& Griffin op. cit.

${ }^{81}$ J Defterios. "ISIS: Can coalition cut off funding of world's wealthiest terror group?" CNN. 27 October 2014.

<http://edition.cnn.com/2014/10/27/business/isis-wealthiest-terror-groupdefterios/iref=obnetwork $>$ Accessed on 26 November 2014.

82 Tilsley op. cit.

${ }^{83} \mathrm{~N}$ Shaikh. "Focus on ISIS is R78m airport probe". Independent Online. 20 September 2015. <http://mobi.iol.co.za/\#!/focus-on-isis-in-r78m-airport-probe1.918566> Accessed on 28 September 2015.

${ }^{84} \mathrm{Al}$-Tamimi op. cit.

${ }^{85}$ Almukhtar op. cit.

${ }^{86}$ Weiss \& Hassan op. cit., p. 124.

${ }^{87}$ Ibid., p. 126.

${ }^{88}$ Ibid., pp. $128-129$.

${ }^{89}$ Alexander \& Beach op. cit. 
${ }^{90} \mathrm{~T}$ Arango \& A Barnard. "With victories, IS dispels hope of a swift decline”. The New York Times. 23 May 2015.

<http://nytimes.com/2015/05/24/world/middleeast/with-victories-IS-dispels-hopeof-a-swift-decline.html > Accessed on 2 June 2015.

${ }^{91}$ Ibid.

${ }^{92}$ Ibid.

93 Ibid.

94 Ibid.

95 Ibid.

96 Ibid.

97 Ibid.

${ }^{98}$ J Spyer. "Dispatch from Iraq: Iran-backed militias keep IS at bay, for a price". The Australian. 4 July 2015. <http://www.meforum.org/5365/iraq-iranmilitia-IS $>$ Accessed on 8 July 2015.

${ }^{99}$ T Arango. "IS suicide attack kills 2 Iraqi generals near Ramadi". The New York Times. 27 August 2015.

<http://www.nytimes.com/2015/08/28/world/middleeast/iraq-IS-suicide-attackramadi.html $>$ Accessed on 31 August 2015.

100 Ibid.

101 "Libya profile - Timeline". BBC. 27 May 2015.

<http://www.bbc.com/news/world-africa-13766445> Accessed on 2 June 2015.

102 Ibid.

103 SA Zway \& DD Kirkpatrick. "Western officials alarmed as IS expands

territory in Libya". New York Times. 31 May 2015.

<http://www.nytimes.com/2015/06/01/world/africa/western-officials-alarmed-as-

islamic-state-expands-territory-in-libya.html> Accessed on 2 June 2015.

104 "Suicide bombing claimed by Islamic State in western Libyan city kills

five: Official”. Reuters. 31 May 2015.

<http://www.reuters.com/article/2015/05/31/us-libya-security-

idUSKBN0OG09220150531> Accessed on 2 June 2015.

${ }^{105}$ Zway \& Kirkpatrick op. cit.

106 "Islamic state militants in Libya seize Sirte airport”. BBC. 29 May 2015. <http://www.bbc.com.news/world-world-africa-32935412>Accessed on 2 June 2015 .

107 “Libya fears Iraq-like IS scenario". News 24.com. 2 June 2015.

<http://www.news24.com/Africa/News/Libya-fears-Iraq-like-IS-scenario$20150601>$ Accessed on 2 June 2015.

${ }^{108} \mathrm{~S}$ Tomlinson. "IS opens new front in North Africa after two extremist groups in Libya and Egypt pledge allegiance to its terror chief'. Mail Online. 2 December 2014. <www.dailymail.co.uk/news/article2853255/IS-opens-newextremist-groups-Libya-Egypt-pledge-allegiance-terror-leader.html > Accessed on 10 March 2015.

${ }^{109} \mathrm{~S}$ Allison. "Think again - too late to start worrying about the Islamic State in Africa". ISS Africa. 7 October 2014.

${ }^{110}$ Quoted in H Solomon. Islamic State and the Coming Global

Confrontation. Palgrave, London, 2016, p. 91. 
${ }^{111}$ Quoted in A Chandler. "Tunisia after the museum attack". The Atlantic. 1 April 2015. <www.theatlantic.com/international/archive/2015/03/tunisia-in-bardosaftermath/389039> Accessed on 1 April 2015.

${ }^{112}$ E Byrne \& C Stephen. "Tunisian and French presidents attend unity rally after Tunis museum attack". The Guardian. 29 March 2015.

<http://theguardian.com/world/2015/mar/29/Tunisian-french-presidents-unity-rallytunis-museum-attack> Accessed on 1 April 2015.

${ }^{113} \mathrm{C}$ Gall. "Official says that commander of group that massacred 21 in Tunisia is dead". The New York Times. 19 March 2015.

<http://www.nytimes.com/2015/03/30/world/africa/official-says-commander-ofgroup-that-massacred-21-in-tunisia-is-dead.html> Accessed on 2 April 2015.

${ }^{114}$ France24.com op. cit.

115 J Keaten \& P Schemm. "Islamic State claims responsibility for Tunisia attack”. Associated Press. 30 March 2015.

$<$ http://wfsb.com/story/28558893/islamic-state-claims-responsibility-for-tunisiaattack $>$ Accessed on 1 April 2015.

${ }^{116} \mathrm{~T}$ Thornhill. “Children's worker reveals how mother's suicide helped turn the Kouachi brothers from 'sweet young boys' into infamous Islamist murderers". Mail Online. 19 January 2015. <http://www.dailymail.co.uk/news/article2916450/Chidren-s-worker-reveals-Kouachi-brother-s-sweet-young-boys-infamousIslamists-murderers.html>Accessed on 12 September 2015.

${ }^{117} \mathrm{H}$ Saul. "Paris attacks timeline: From Charlie Hebdo to a Jewish grocery store - how two hostage situations unfolded". The Independent. 9 January 2015. <http://www.independent.co.uk/europe/paris-attacks-timelne-from-charlie-hebdo-todammartinengoele-how-the-double-hostage-situation-unfolded-9968543.html > Accessed on 12 September 2015.

118 A Chrisaftis. "Charlie Hebdo attackers' born, raised and radicalized in Paris.” The Guardian. 12 January 2015.

<http://www.theguardian.com/world/2015.jan/12-sp-charlie-hebdo-attackers-kidsfrance-radicalised-paris $>$ Accessed on 12 September 2015.

${ }^{119}$ Von Drehle op. cit., p. 18.

${ }^{120}$ Ibid.

${ }^{121}$ Ibid.

122 Ibid.

123 T Parfitt. "ISIS claims Paris attacks as revenge for Syrian airstrikes and insulting Islam's prophet”. Sunday Express. 15 November 2015. <http://www.express.co.uk/news/world/619363/Islamic-State-ISIS-Twitter-Parisattacks> Accessed on 15 November 2015.

${ }^{124} \mathrm{P}$ Szodra. "ISIS is losing massive amounts of territory - Here's what they've left behind”. Nordic Business Insider. 26 January 2017. <nordicbusinessinsider.com/what-isis-leaves-behind-2017-1> Accessed on 4 April 2017.

125 "London attack: What we know so far". BBC. 3 April 2017. <http://www.bbc.com/news/uk-39355108> Accessed on 4 April 2017. 
126 T Lister. "St. Petersburg metro station: At least 11 dead in Russia blast". CNN. 3 April 2017. <http://edition/cnn.com/2017/04/03/europe/st-petersburg-russiaexplosion/index/html $>$ Accessed on 4 April 2017. 